\title{
POPULASI DAN SERANGAN LIRIOMYZA SATIVAE (BLANCHARD) (DIPTERA: AGROMYZIDAE), SERTA POTENSI PARASITOIDNYA PADA PERTANAMAN KETIMUN
}

\author{
Siti Herlinda ${ }^{1}$, Leny Puspa Rosalina1, Yulia Pujiastuti ${ }^{1}$, Erizal Sodikin ${ }^{2}$, dan Aunu Rauf ${ }^{3}$
}

\begin{abstract}
Population and damage by Liriomyza sativa (Blanchard) (Diptera : Agromyzidae) and its parasitoid potential on cucumber fields. The objectives of this research were to figure out adult population of L. sativae and the damage caused by the larvae on cucumber leaves, to analyze the relationship between adult population and the number of leaf mining tunnel caused by $L$. sativae larvae, and to analyze the relationship betweeen the larval abundance and its parasitoids. The highest adult population (7.60 adults per trap) of L. sativae was found on 5 weeks after planting (WAP) and the lowest (3.20 adults per trap) was on 2 WAP. The highest damage intensity was found on 3 weeks after planting, amounted to $36.89 \%$ while the lowest was found on 6 weeks after planting, amounted to $12.12 \%$. The regression coefficient showed that each adult of $L$. sativae caused one leaf mining tunnel. The higher the number of $L$. sativae larvae, the more the mining tunnels occured $(\mathrm{R}=80.8 \%)$. The higher the number of $L$. sativae larvae in cucumber leaves, the more the larvae parasitized $(\mathrm{R}=86.8 \%)$. Parasitoids found were Diglyphus sp. (Hymenoptera : Eulophidae) and Neochrysocharis sp. (Hymenoptera : Eulophidae). The highest apparent parasitism was found on 5 weeks after planting, amounted to $41.9 \%$.
\end{abstract}

Key words: damage, Liriomyza sativae, parasitoid, population

\section{PENDAHULUAN}

Dalam upaya peningkatan produksi ketimun (Cucumis sativus Linn.) banyak kendala yang dihadapi antara lain serangan hama pengorok daun, Liriomyza sativae (Blanchard) (Diptera: Agromyzidae). L. sativae adalah hama pendatang baru yang masuk ke Indonesia sekitar tahun 1996 (Rauf et al., 2000).

Tanaman yang terserang $L$. sativae memperlihatkan gejala berupa bintik - bintik putih akibat tusukan ovipositor (Mau \& Kessing, 1991), dan liang korokan memiliki ciri khas berbentuk linear, mengular (serpentine), dan korokannya lebih lebar daripada korokan spesies lain (Murphy \& LaSalle, 1999). Akibat serangan hama ini, daun mengering dan berwarna coklat seperti terbakar (Mau \& Kessing, 1991; Rauf, 2001). Pada keadaan populasi tinggi, serangan dapat menyebabkan kegagalan panen atau kematian tanaman (Spencer, 1989). Serangan L. sativae pada tanaman ketimun di Jawa Barat dapat menyebabkan kehilangan hasil hingga 60\% (Rauf, 2001).

Hama ini sulit dikendalikan secara kimiawi dan telah dilaporkan resisten terhadap insektisida (Mason et al., 1987). Saat ini upaya pengendalian L. sativae lebih difokuskan pada pengendalian hama terpadu (PHT) yang komponen utamanya adalah pengendalian hayati. Dalam PHT, informasi tentang ekologi hama yang akan dikendalikan sangat diperlukan.

Walaupun, L. sativae sekarang telah dilaporkan tersebar hampir di seluruh wilayah Indonesia (Rauf \& Shepard, 2001), termasuk Sumatera Selatan (Herlinda et al., 2003), namun hingga saat ini belum pernah dilaporkan tentang ekologi $L$. sativae pada tanaman ketimun. Oleh karena itu, kajian ekologi L. sativae pada tanaman ketimun perlu dilakukan yang meliputi populasi imago dan intensitas serangan larva L. sativae, menganalisis hubungan antara populasi imago dengan jumlah korokan larva $L$. sativae, serta menganalisis hubungan antara kelimpahan larva L. sativae dengan kelimpahan parasitoidnya.

\section{METODE PENELITIAN}

Penelitian ini dilaksanakan di pertanaman ketimun di daerah Inderalaya, Ogan Ilir, Sumatera Selatan dari bulan Januari sampai Juli 2005.

Penentuan Lokasi Penelitian. Lokasi penelitian yang luasnya $1200 \mathrm{~m}^{2}$, terletak di lahan pertanaman ketimun milik petani di Inderalaya. Lahan pertanaman tersebut dibagi menjadi empat subpetak, yang setiap subpetak berukuran $300 \mathrm{~m}^{2}$.

Pengamatan Populasi Imago. Kelimpahan populasi imago L. sativae diamati dengan menggunakan

\footnotetext{
${ }^{1}$ Dosen Jurusan Hama dan Penyakit Tumbuhan, Faperta, Universitas Sriwijaya Email:linda_hasbi@pps.unsri.ac.id

2 Dosen Jurusan Budidaya Pertanian, Faperta, Universitas Sriwijaya Kampus Inderalaya, Ogan Ilir, Inderalaya 30662

${ }^{3}$ Dosen Departemen Proteksi Tanaman, Faperta, IPB, Kampus Darmaga, Bogor 16680
} 
perangkap kuning seperti yang dilakukan oleh Robin dan Mitchell (1985). Perangkap berukuran 10 x 18 $\mathrm{cm}^{2}$ dengan kedua sisinya dilapisi lem lalat. Perangkap dipasang pada ketinggian $50 \mathrm{~cm}$, atau sekitar pertengahan tajuk ketimun. Perangkap dipasang selama 3 x 24 jam. Pemasangan perangkap dilakukan setiap minggu sejak tanaman berumur 2 minggu setelah tanam (mst) hingga panen (11 mst). Banyaknya perangkap yang dipasang pada tiap subpetak contoh adalah 5 buah yang tersebar sesuai arah diagonal.

\section{Pengamatan Kelimpahan Larva $L$ sativae dengan}

Parasitoidnya. Kelimpahan parasitoid dilakukan dengan cara mengambil contoh daun ketimun yang terserang L. sativae. Untuk tiap subpetak diambil secara acak sebanyak 10 helai daun (total 40 helai). Pengambilan daun contoh ini dilakukan setiap minggu, sejak tanaman berumur 2-11 mst. Di laboratorium daun-daun tadi lalu dimasukkan ke dalam silinder plastik (diameter $20 \mathrm{~cm}$ dan tinggi 25 $\mathrm{cm}$ ) yang dialasi jalinan kawat agar tersedia ruangan antara daun dan dasar wadah. Setiap hari banyaknya lalat L. sativae dan imago parasitoid yang muncul dihitung dan dicatat. Imago parasitoid kemudian dimasukkan ke dalam botol vial yang berisi alkohol $70 \%$ untuk diidentifikasi.

Pengamatan Korokan Larva. Pada saat yang bersamaan dengan pengumpulan daun untuk penentuan kelimpahan larva $L$ sativae dengan parasitoid di atas, sebanyak empat helai daun diambil secara acak dari tiap subpetak. Di laboratorium banyaknya korokan dan banyaknya larva $L$. sativae yang hidup atau mati pada tiap helai dihitung dengan bantuan mikroskop binokuler.

Pengamatan Intensitas Serangan. Penelitian dilakukan pada pertanaman ketimun (pertanaman yang sama dengan lokasi pengamatan populasi imago). Kerusakan tanaman ketimun akibat serangan L. sativae diamati secara langsung pada daun-daun pada tanaman contoh (10\% dari populasi tanaman). Pengamatan ini dilakukan setiap minggu, sejak tanaman berumur 2 mst hingga panen (11 mst).

Penentuan tingkat kerusakan dilakukan dengan menilai kerusakan tanaman menggunakan skala 1-5 berdasarkan kriteria berikut (Raman et al. 1994):
1 = tidak ada kerusakan

2 = kerusakan kecil, umunya terbatas pada bagian bawah tanaman, sekitar 1-25\% kerusakan

3 = kerusakan sedang, umunya terbatas pada bagian bawah dan tengah tanaman, > 25$50 \%$ kerusakan

4 = kerusakan pada seluruh bagian tanaman kecuali daun-daun pucuk, > 50-75\% kerusakan

5 = sebagian besar dari keseluruhan bagian tanaman rusak, > 75-100\% kerusakan

Analisis data. Nilai rataan populasi imago dan larva L. sativae, kelimpahan dan parasitisme kentara dari tiap parasitoid serta tingkat kerusakan tanaman dihitung dengan rataan tertimbang. Kecenderungan perubahan kelimpahan dan tingkat kerusakan dari waktu ke waktu ditampilkan dalam bentuk kurva atau histogram. Analisis regresi diterapkan untuk memeriksa hubungan populasi imago $L$. sativae dengan banyaknya korokan pada daun, serta kelimpahan larva $L$ sativae dengan parasitoid, dengan bantuan program MINITAB versi 11.12. Nilai rataan tingkat kerusakan tanaman dihitung. Kecenderungan perubahan tingkat serangan dari waktu ke waktu ditampilkan dalam bentuk kurva atau histogram.

\section{HASIL DAN PEMBAHASAN}

\section{Hasil}

Populasi dan Serangan $L$. sativae pada Pertanaman Ketimun. Populasi imago L. sativae mulai ditemukan saat tanaman berumur 2 mst, yaitu sebesar 3,10 ekor/perangkap dan puncak populasi terjadi saat tanaman berumur 5 mst (Gambar 1). Populasi meningkat pada awal tanam sampai muncul bunga dan setelah itu menurun hingga tanaman berumur 11 mst.

Dari hasil pengamatan diketahui bahwa serangan dari $L$. sativae paling tinggi mencapai $36,89 \%$ pada saat tanaman berumur 3 mst (Gambar 2). Serangan larva $L$. sativae mengalami penurunan setelah tanaman berumur 3 hingga 11 mst. 


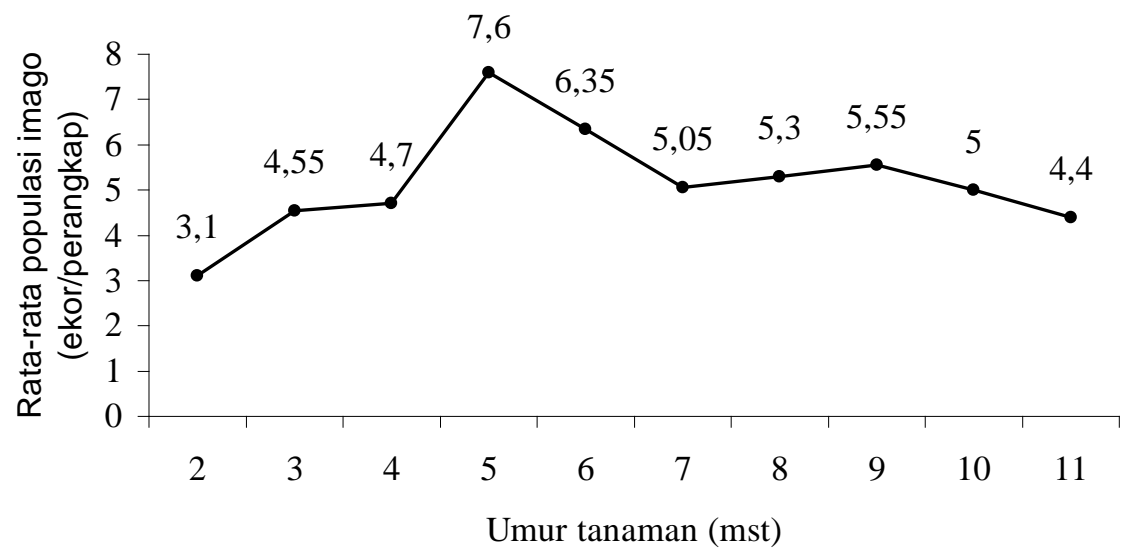

Gambar 1. Perkembangan populasi L. sativae pada pertanaman ketimun.

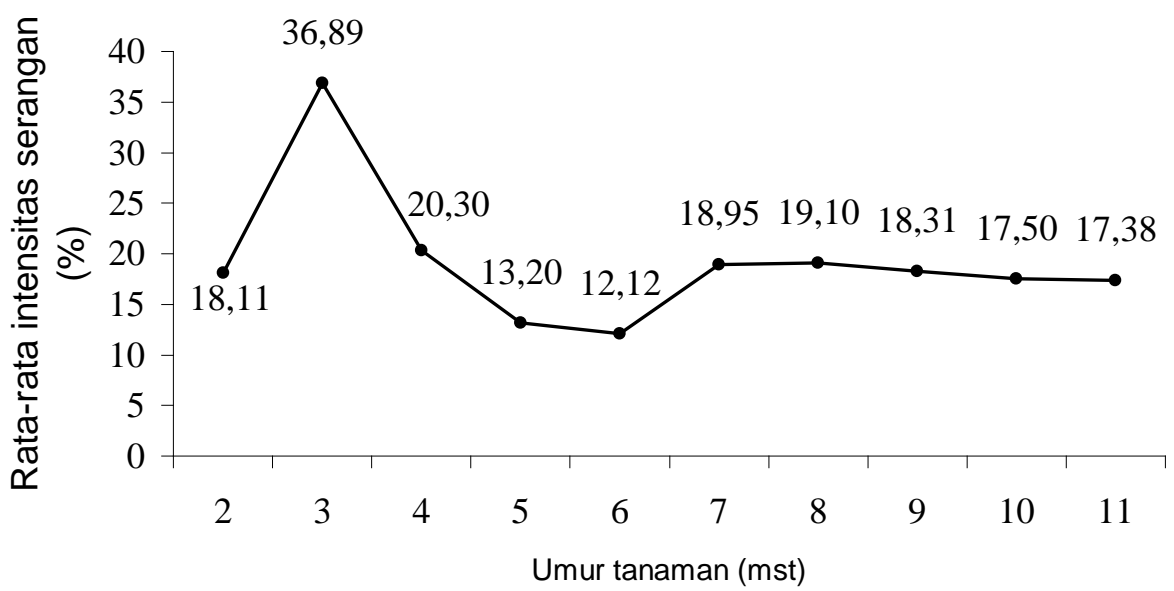

Gambar 2. Intensitas serangan larva L. sativae pada pertanaman ketimun.

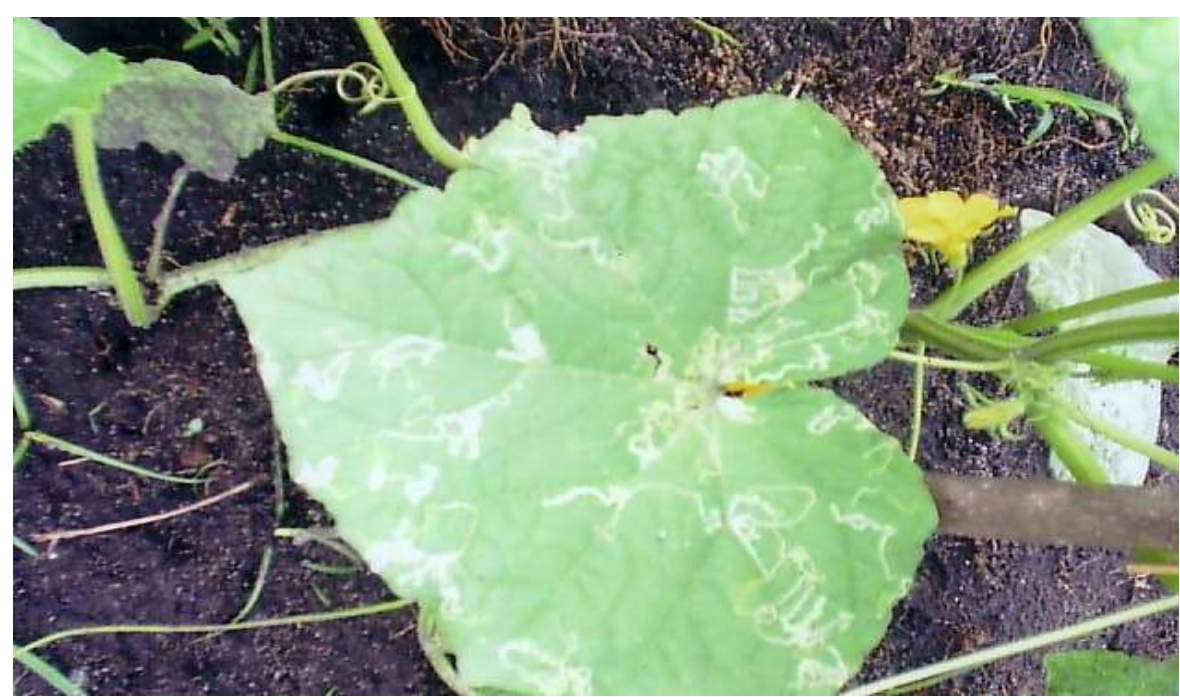

Gambar 3. Gejala serangan L. sativae pada daun ketimun. 
Gejala awal serangan L. sativae ditunjukkan oleh adanya bintik-bintik putih dan korokan berupa terowongan kecil yang berliku pada permukaan bagian atas daun (Gambar 3). Bintik putih dan korokan tersebut hanya terdapat pada permukaan bagian atas daun, sedangkan permukaan daun bagian bawah tidak terdapat bintik putih ataupun korokan. Serangan berat mengakibatkan korokan tersebut mengering dan berwarna coklat seperti daun terbakar.

Dari hasil pengamatan bagian tanaman yang terserang di lapangan terlihat bahwa tajuk bawah merupakan bagian yang paling banyak diserang bila dibandingkan dengan tajuk atas. Intensitas serangan pada tajuk bawah berkisar 23,71-73,26\%, sedangkan pada tajuk atas hanya berkisar 0 - 4\% (Tabel 1).

Tajuk atas dimulai dari pertengahan tajuk tanaman hingga daun paling atas, sedangkan tajuk bawah dimulai dari pertengahan tajuk tanaman hingga ke permukaan tanah

\section{Populasi Imago L. sativae dan Korokan Larvanya.} Jumlah korokan larva meningkat dengan meningkatnya populasi imago. Koefisien regresi $(\mathrm{b}=$ 17) menunjukkan, bahwa setiap ekor imago L. sativae dapat menghasilkan satu korokan larva. Hubungan regresi tersebut sangat nyata secara statistik pada taraf $\mathrm{P}<0,001$ dengan koefisien determinan (R) 80,8\% yang berarti korokan berkorelasi positif dengan populasi imago, semakin tinggi populasi imago semakin banyak juga korokan yang diakibatkan oleh larvanya (Gambar 4).

Perkembangan jumlah korokan terkait dengan perkembangan jumlah larva. Korokan semakin banyak dengan semakin banyaknya larva yang terdapat pada daun ketimun (Tabel 2). Perkembangan jumlah korokan dan larva L. sativae terus meningkat dengan semakin meningkatnya umur tanaman ketimun.

Kelimpahan Larva $L$. sativae dan Parasitoidnya. Parasitoid yang ditemukan pada penelitian ini adalah Diglyphus sp. (Hymenoptera: Eulophidae) dan Neochrysocharis sp. (Hymenoptera: Eulophidae) Parasitisme kentara mulai ditemukan sejak tanaman berumur 3 mst, yaitu sebesar 6,25\% (Tabel 3). Puncak Parasitisme kentara terjadi saat bunga mulai muncul, yaitu sebesar $42,86 \%$, setelah itu mulai turun hingga tanaman berumur 11 mst.

Dari persamaan regresi $(\mathrm{y}=-6,13+0,62 \mathrm{x})$ menunjukkan bahwa setiap 14 ekor larva $L$. sativae dapat diparasit sebanyak 2,60 ekor. Hubungan regresi tersebut sangat nyata secara statistik pada taraf $\mathrm{P}<0.001$ dengan $\mathrm{R}=86,8 \%$ yang berarti kelimpahan parasitoid berkorelasi positif dengan kelimpahan larva L. sativae, semakin tinggi jumlah larva di daun semakin banyak juga parasitoid yang muncul dari larva tersebut (Gambar 5).

Dari persamaan regresi $(y=-6,13+0,62 x)$ menunjukkan bahwa setiap 14 ekor larva $L$. sativae dapat diparasit sebanyak 2,60 ekor. Hubungan regresi tersebut sangat nyata secara statistik pada taraf $\mathrm{P}<0.001$ dengan $\mathrm{R}=86,8 \%$ yang berarti kelimpahan parasitoid berkorelasi positif dengan kelimpahan larva L. sativae, semakin tinggi jumlah larva di daun semakin banyak juga parasitoid yang muncul dari larva tersebut (Gambar 5).

\section{Pembahasan}

Imago L. sativae mulai ditemukan pada tanaman ketimun berumur 2 mst. Hasil yang didapat sejalan dengan laporan Herlinda (2004a) di pertanaman kubis, yaitu ditemukan imago

Tabel 1. Sebaran vertikal kerusakan daun tanaman ketimun akibat serangan larva $L$. sativae

\begin{tabular}{ccc}
\hline \multirow{2}{*}{ Umur tanaman $(\mathrm{mst})$} & \multicolumn{2}{c}{ Rata-rata serangan (\%) pada daun: } \\
\cline { 2 - 3 } & tajuk atas & tajuk bawah \\
\hline 2 & 0,00 & 31,66 \\
3 & 0,18 & 73,26 \\
4 & 0,22 & 39,81 \\
5 & 0,16 & 26,11 \\
6 & 0,38 & 23,71 \\
7 & 3,31 & 34,43 \\
8 & 4,00 & 34,04 \\
9 & 3,97 & 32,52 \\
10 & 3,81 & 31,02 \\
11 & 3,84 & 30,81 \\
\hline
\end{tabular}


Tabel 2. Perkembangan jumlah korokan dan larva L. sativae pada daun ketimun selama satu musim tanam

\begin{tabular}{ccccc}
\hline \multirow{2}{*}{$\begin{array}{c}\text { Umur tanaman } \\
(\mathrm{mst})\end{array}$} & $\begin{array}{c}\text { Rata-rata korokan } \\
\text { per 4 daun }\end{array}$ & \multicolumn{2}{c}{ Rata-rata larva (ekor/4 daun) } & \multirow{2}{*}{$\begin{array}{c}\text { Total larva } \\
\text { (ekor/4 daun) }\end{array}$} \\
\hline 2 & 9,00 & 6,25 & 0,50 & 6,75 \\
3 & 42,75 & 5,00 & 19,00 & 24,00 \\
4 & 60,25 & 15,25 & 8,00 & 23,25 \\
5 & 74,00 & 15,75 & 9,75 & 25,50 \\
6 & 77,75 & 22,25 & 12,75 & 35,00 \\
7 & 76,25 & 24,25 & 10,75 & 35,00 \\
8 & 80,00 & 19,00 & 12,75 & 31,75 \\
9 & 78,50 & 22,25 & 11,75 & 34,00 \\
10 & 79,50 & 27,00 & 12,25 & 39,25 \\
11 & 74,00 & 23,25 & 13,00 & 36,25 \\
\hline
\end{tabular}

Tabel 3. Parasitisme kentara larva L. sativae yang ditemukan pada tanaman ketimun

\begin{tabular}{ccccccc}
\hline \multirow{2}{*}{$\begin{array}{c}\text { Umur } \\
\text { tan. } \\
\text { (mst) }\end{array}$} & \multicolumn{2}{c}{ Rataan (ekor/10 daun): } & Rataan parasitisme kentara (\%): & Total \\
\cline { 2 - 6 } & L. sativae & $\begin{array}{c}\text { imago } \\
\text { muncul } \\
\text { L. sativae }\end{array}$ & $\begin{array}{c}\text { parasitoid } \\
\text { muncul }\end{array}$ & \multicolumn{3}{c}{ Neochrysocharis } \\
sp. & \\
\hline 2 & 10,75 & 9,75 & 0,00 & 0,00 & 0,00 & 0,00 \\
3 & 13,75 & 11,25 & 0,75 & 6,21 & 0,04 & 6,25 \\
4 & 12,00 & 10,25 & 1,50 & 10,61 & 2,17 & 12,77 \\
5 & 20,75 & 11,00 & 8,25 & 20,12 & 22,74 & 42,86 \\
6 & 20,75 & 14,00 & 6,00 & 18,52 & 11,48 & 30,00 \\
7 & 18,75 & 12,75 & 5,25 & 14,64 & 14,54 & 29,17 \\
8 & 18,00 & 13,25 & 4,75 & 16,04 & 10,35 & 26,39 \\
9 & 16,00 & 12,00 & 3,50 & 13,96 & 8,62 & 22,58 \\
10 & 15,75 & 13,25 & 1,50 & 2,63 & 7,54 & 10,17 \\
11 & 13,50 & 11,25 & 0,75 & 4,42 & 1,83 & 6,25 \\
\hline
\end{tabular}


Jumlah korokan/4 daun

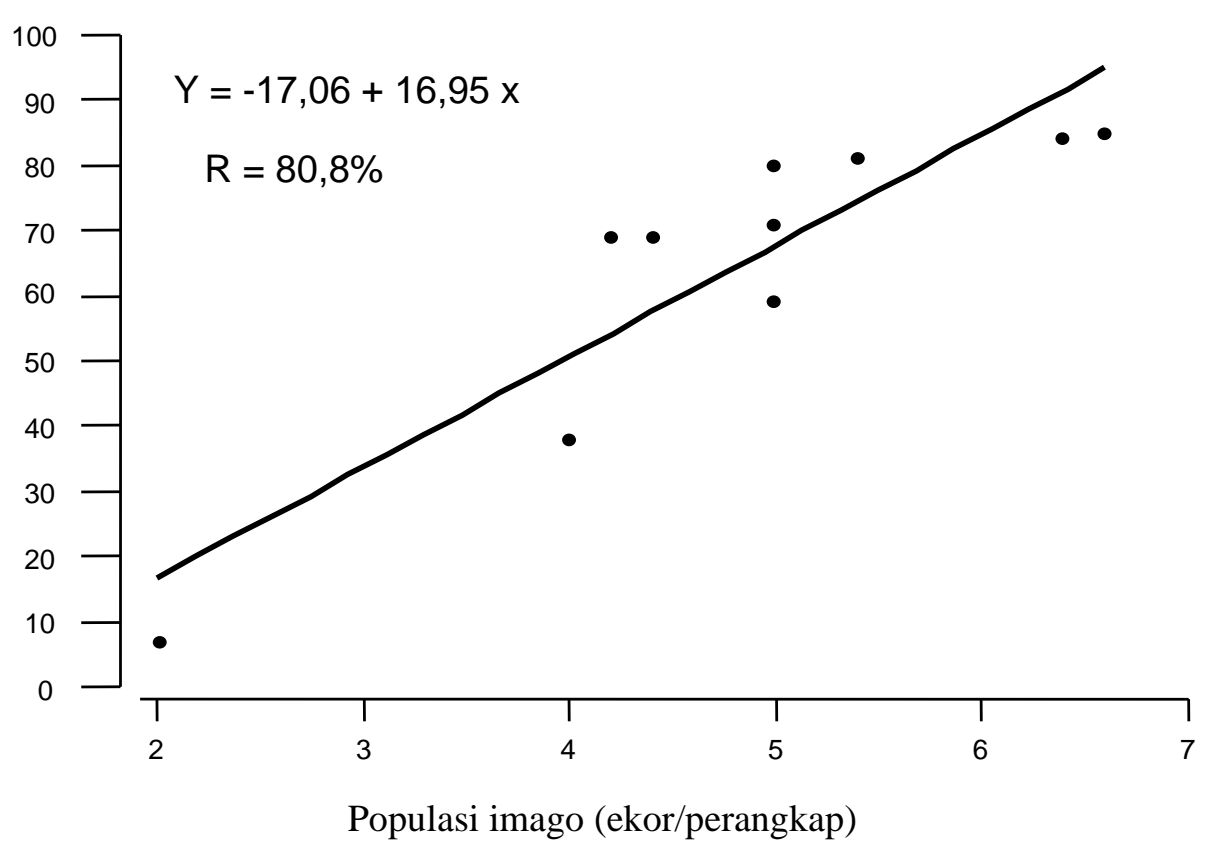

Gambar 4. Hubungan antara banyaknya jumlah imago L. sativae dengan korokan.

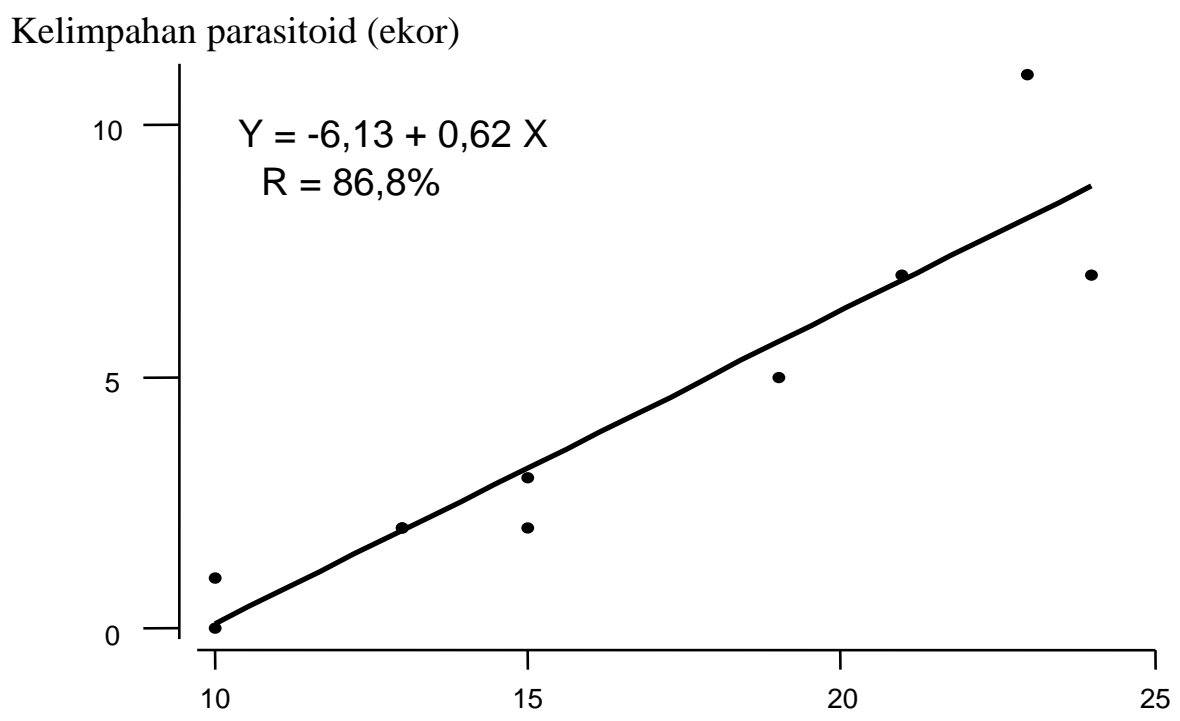

Kelimpahan larva L. sativae (ekor)

Gambar 5. Hubungan antara kelimpahan larva L. sativae dengan parasitoidnya. 
L. huidobrensis saat 2 mst. Populasi imago dapat ditemukan lebih awal apabila perangkap kuning dipasang lebih awal karena hasil pengamatan Rauf (2001) menunjukkan larva L. sativae mulai menyerang sejak kotiledon terbentuk artinya imago sudah ada di lapangan di awal penanaman. Pada penelitian ini, L. sativae telah berada di pertanaman sebelum tanaman ketimun ditanam karena sumber koloni hama ini adalah tanaman inang di sekitarnya, seperti terong dan gulma. Dengan demikian, sebelum budidaya tanaman sayuran seperti ketimun perlu diperhatikan keberadaan hama ini pada pertanaman di sekitarnya. Berdasarkan hasil pengamatan langsung di lapangan, jenis tanaman tertentu, seperti cabai jarang atau tidak diserang sama sekali oleh hama ini. Tanaman yang dapat menjadi sumber koloni penting, yaitu tomat, tomat ranti, kacang panjang, dan kacang buncis.

Populasi imago meningkat pada awal tanam sampai muncul bunga, lalu terus menurun. Peningkatan populasi imago hingga menjelang fase generatif ini karena ketersediaan daun untuk tempat bertelur lalat betina meningkat juga. Memasuki fase generatif mulai terjadi penurunan populasi imago di pertanaman. Penurunan ini erat kaitannya dengan kesesuaian pakan untuk larvanya, hal ini akan dibahas kemudian. Fenomena seperti ini dilaporkan Herlinda (2003) di pertanaman tomat ranti. Dengan demikian, sebaiknya populasi imago $L$. sativae sudah dapat diturunkan saat awal tanam hingga menjelang fase generatif. Penurunan populasi dapat dilakukan secara sederhana dengan pemasangan perangkap kuning, namun penelitian ini tidak mengkaji jumlah dan frekuensi pemasangan yang efektif untuk dapat menekan populasi imago L. sativae. Rauf (1999) melaporkan perangkap berupa helaian kain berperekat yang ditarik setiap hari di atas tajuk kentang efektif menekan populasi lalat Liriomyza.

Semakin banyak imago L. sativae di lapangan, maka semakin banyak juga korokan yang terbentuk oleh larva. Populasi imago yang tinggi menyebabkan semakin banyak larva yang terbentuk sehingga korokannya semakin banyak. Pada penelitian ini didapatkan data korelasi dengan koefisien determinan yang tinggi antara kelimpahan imago dengan korokan larva. Dengan demikian, bila kita ingin memprediksi kerusakan daun karena larva L. sativae dapat melalui data populasi imagonya. Populasi imago di pertanaman lebih mudah dimonitor dengan menggunakan perangkap kuning tanpa harus mengamati keberadaan larva dan korokannya.

Kerusakan daun yang berupa bintik-bintik putih merupakan akibat dari tusukan ovipositor imago L. sativae, sedangkan korokan yang berliku-liku atau mengular disebabkan oleh aktivitas larva $L$. sativae saat memakan jaringan daun. Rauf et al. (1999) menyatakan bahwa kerusakan oleh $L$. huidobrensis karena lalat betina menusuk permukaan atas atau bawah daun dengan ovipositornya. Lalat betina dan jantan kemudian makan cairan daun yang keluar dari tusukan tadi. Penusukan juga dilakukan oleh lalat betina pada saat menyisipkan telurnya ke dalam jaringan daun. Larva yang baru keluar dari telur segera mengorok dan memakan jaringan mesofil daun, dan tinggal dalam liang korokan hingga menjelang fase prapupa. Serangan berat, daun tanaman inang tampak seperti terbakar.

Intensitas serangan $L$. sativae mengalami peningkatan pada awal tanam sampai menjelang fase generatif, namun setelah itu mengalami penurunan. Hal ini disebabkan karena pada fase vegetatif sampai awal fase generatif kandungan nutrisi pada daun masih tinggi, permukaan daun cukup luas dan daundaun pada tajuk bawah belum gugur sehingga memungkinkan serangan larva $L$. sativae tinggi. Pada saat tanaman mulai berbunga hingga panen terjadi penurunan serangan. Supartha (1998) melaporkan bila tanaman telah memasuki fase generatif kandungan protein daun berkurang karena telah disalurkan ke buah sehinga kurang sesuai untuk pertumbuhan dan perkembangan larva.

Tajuk bagian bawah lebih banyak diserang L. sativae karena daun bagian bawah lebih banyak mengandung nutrisi yang dibutuhkan oleh imago dan larva. Supartha (1998) melaporkan bahwa daun-daun pada tajuk bawah mengandung kadar fenol yang lebih rendah jika dibandingkan pada tajuk atas. Kadar fenol yang tinggi kurang disukai $L$. sativae. Fenol kentang dapat berperan sebagai penangkal makan dan oviposisi bagi imago. Lebar daun juga mempengaruhi pemilihan inang oleh imago L. sativae. Daun yang lebih lebar lebih banyak terserang dibandingkan daun yang sempit. Selain itu, ada kecenderungan imago L. sativae melakukan aktivitas makan dan oviposisi pada ketinggian tertentu. Supartha (1998) menyatakan secara kumulatif sekitar 92\% aktivitas penerbangan imago L. huidobrensis berada pada ketinggian 15-45 cm di atas permukaan tanah. 
Parasitisme kentara mulai ditemukan 3 mst, artinya parasitoid mulai memarasit larva L.sativae sejak umur tersebut. Parasitoid banyak terdapat di lapangan saat bunga ketimun mulai muncul dan mengalami penurunan menjelang panen. Hal ini disebabkan bunga ketimun merupakan daya tarik bagi induk parasitoid untuk lebih sering berkunjung ke pertanaman karena bunga merupakan sumber pakannya. Selain itu, Susilawati (2002) menyatakan meningkatnya kelimpahan parasitoid $L$. sativae di pertanaman dipengaruhi oleh kelimpahan larva pada daun tanaman inang. Semakin tinggi jumlah larva semakin banyak juga parasitoid dapat memarasitnya. Kenyataan ini didukung oleh tingginya korelasi antara kelimpahan larva L. sativae dengan kelimpahan parasitoidnya (Gambar 5). Parasitoid yang efektif cenderung mengikuti perkembangan populasi inangnya. Hal ini sejalan dengan hasil penelitian Herlinda (2004b) pada parasitoid Diadegma semiclausum (Hellen) yang mengikuti perkembangan populasi Plutella xylostella (L.). Bila populasi inang meningkat, maka jumlah inang yang terparasit meningkat juga.

\section{SIMPULAN DAN SARAN}

Imago L. sativae mulai ditemukan di pertanaman ketimun yang baru berumur 2 mst. Populasi imago L. sativae mengikuti perkembangan tanaman, populasi meningkat pada awal tanam sampai hingga menjelang fase generatif. Intensitas serangan larva $L$. sativae paling tinggi (36,8\%) saat tanaman berumur 3 mst. Semakin banyak populasi imago di pertanaman, semakin banyak korokan larva yang terbentuk $(\mathrm{R}=80,8 \%)$. Semakin tinggi jumlah larva L. sativae pada daun ketimun, semakin banyak juga larva yang terparasit $(\mathrm{R}=86,8 \%)$, yang diindikasikan dengan jumlah imago parasitoid yang muncul. Parasitoid yang ditemukan adalah Diglyphus sp. dan Neochrysocharis sp. Parasitisme kentara yang paling tinggi $(42,8 \%)$ terjadi pada saat tanaman berumur 5 mst.

Dari hasil penelitian ini disarankan agar dilaksanakan penelitian lanjutan tentang jumlah dan frekuensi pemasangan perangkap kuning per ha di pertanaman ketimun sehingga didapatkan informasi tentang jumlah dan frekuensi pemasangan perangkap yang efektif menekan populasi dan serangan L. sativae.

\section{SANWACANA}

Penelitian ini merupakan bagian dari Penelitian Hibah Bersaing, DP3M, Dikti, Diknas Tahun Anggaran 2005 dengan kontrak nomor: 021/SPPP/PP/DP3M/IV/2005, tanggal 11 April 2005. Spesies parasitoid diidentifikasi oleh Dr. Chandra Irsan untuk itu kami mengucapkan terima kasih.

\section{DAFTAR PUSTAKA}

Herlinda, S. 2003. Ecology of Liriomyza spp. (Diptera: Agromyzidae) in field vegetables in South Sumatera. Pages 60-66 in: Proceedings of an International Seminar on Organic Farming and Sustainable Agriculture in the Tropics and Subtropics, Palembang October 8-9, 2003. Sriwijaya University Publishers, Inc. Palembang.

Herlinda, S. 2004a. Jenis tumbuhan inang, populasi, dan kerusakan oleh penggorok daun Liriomyza huidobrensis (Blanchard) pada tanaman kubis (Brassica oleracea L.). Jurnal Tanaman Tropika 5(1): 59-68.

Herlinda, S. 2004b. Dinamika interaksi parasitoid dengan inangnya, Plutella xylostella (Linn.) (Lepidoptera: Plutellidae) pada sayuran Brasicaceae. Agria 1(1): 10-17.

Herlinda, S., Ismail, \& Y. Pujiastuti. 2003. Populasi dan serangan Liriomyza sp., serta jenis parasitoidnya di pertanaman tomat ranti di Daerah Inderalaya, Sumatera Selatan. Hlm. 110 dalam: Prosiding Seminar Nasional Hasil Riset Bidang Pertanian, BKS-PTN Wilayah Barat Bidang Ilmu-ilmu Pertanian, Universitas Tanjungpura, Pontianak, 9-10 Juni 2003.

Mason G.A., M.W. Johnson, \& B.E. Tabashnik. 1987. Susceptability of Liriomyza sativae and Liriomyza trifolii (Diptera: Agromyzidae) to permethrin and fenvalerate. J. Econ. Entomol. 80(6):1262-1266.

Mau, R.F.L. \& J.L.M. Kessing. 2002. Liriomyza sativae (Blanchard) vegetable leafminer. http://www.extento.hawaii.edu/kbase/croptype/ 
liriom_htm\#biology, diakses 13 Desember 2002).

Murphy, S.T. \& J. LaSalle. 1999. Balancing biological control strategies in the IPM of New World invasive Liriomyza leafminers in field vegetable crops. Biocontrol News and Information 20(3):91-104.

Raman, K.V., A.M. Golmirzaie, M. Palacios, \& J. Tenorio. 1994. Inheritance of resistance to insects and mites. Pages 447-463 in: J.E. Bradshaw \& G. R. Mackay (eds). Potato Genetics. CAB International. Wallingford, UK.

Rauf, A. 1999. Persepsi dan tindakan petani kentang terhadap lalat pengorok daun, Liriomyza huidobrensis (Blanchard) (Diptera: Agromyzidae). Bul HPT. 11(1):1-13.

Rauf, A. 2001. Bioekologi, pamantauan dan pengendalian lalat penggorok daun Liriomyza spp. Makalah Disajikan pada Lokakarya Pengamatan dan Peramalan Organisme Pengganggu Tanaman Hortikultura, Jatisari 1113 September 2001.

Rauf, A. \& B.M. Shepard. 2001. Current status on the biology, ecology and management of Liriomyza spp. in Indonesia with emphasis on Liriomyza huidobrensis. Paper Presented at an International Seminar on Invasive Arthropod of Vegetables and Economic Food Crops, Kuala Lumpur, 13-14 March 2001.
Rauf, A., B.M. Shepard, \& M. W. Johnson. 2000. Leafminers in vegetables in Indonesia: Surveys of host crops, species composition and parsitoids. International Journal of Pest Management 46:257-266.

Rauf, A., I.S. Harahap, \& H. Zakiah. 1999. Hama pengorok daun: Tantangan baru bagi agribisnis bunga di Indonesia dalam: Prosiding pada Workshop Hortikultura II, Bogor, 12 Mei 1999.

Robin M.R. \& W.C. Mitchell. 1985. Sticky traps for monitoring leafminers Liriomyza sativae and Liriomyza trifolii (Diptera: Agromyzidae) and their associated hymenopterous parasites in watermelon. J. Econ. Entomol. 80(6): 13451347.

Spencer, K.A. 1989. Leafminers. Pages 77-98 in: P.R. Kahn (ed.) Plant protection and quarantine Vol II. Selected pests and pathogens of quarantine significance. Boca Raton, FL, USA, CRC Press.

Supartha, I.W. 1998. Bionomi Liriomyza huidobrensis (Blanchard) (Diptera: Agromyzidae) pada tanaman kentang. Disertasi : Program Pascasarjana, Institut Pertanian Bogor.

Susilawati. 2002. Komposisi dan kelimpahan parasitoid lalat penggorok daun, Liriomyza sativae (Blanchard) (Diptera: Agromyzidae). Tesis. Program Pascasarjana, Institut Pertanian Bogor. 